\title{
INTENSIVE SYSTEMS OF PASTURE USE BY SHEEP IN SOUTHLAND
}

\author{
A. J. HARRIS and M. J. HiCKEY
}

Grasslands Division, DSIR, Gore

\section{Abstract}

An experiment comparing two self-contained grazing systems is described in which a high stocking rate of ewes $(23 / \mathrm{ha})$ is compared with a moderate rate (19/ha) which had an induced high lambing percentage. Yields of animal products and pasture utilization patterns are presented and demonstrate the advantage of fitting animal requirements as closely as possible to pasture production. This advantage is emphasized in winter feeding patterns.

Some conclusions on management as it affects the technique of "all grass wintering" in Southland are discussed.

\section{INTRODUCTION}

PASTURE yield estimates obtained at Grasslands Division, Gore, from perennial ryegrass/white clover pasture average $14 \quad 000 \mathrm{~kg} / \mathrm{ha}$ within the range 11000 to $17000 \mathrm{~kg}$. The seasonal distribution of yield, obtained under a defoliation pattern which it was considered would give little stress, is depicted in Fig. 1.

Rankin and Bruce (1972) have described a typical farm on the Southland Plains as being about 120 ha, carrying 1600 ewes, 400 replacements and 40 fattening cattle, and producing 240 $\mathrm{kg} / \mathrm{ha}$ meat and $90 \mathrm{~kg} / \mathrm{ha}$ wool (unscoured). Estimates of pasture production and animal requirements suggest that such a unit is capable of carrying an additional 500 ewes.

Successive attempts at increasing the national production of meat and wool have been based on increases in the rate per hectare of breeding stock. Although initially this was successful in making more effective use of the herbage grown, continued stocking rate increases without changes in grazing management were detrimental. This was demonstrated by the experimental approach of Harris (1960), who adopted continuous grazing from lambing to weaning, followed by rotational grazing for the remainder of the year at rates up to 22 ewes/ha. This system placed considerable stress on pastures in summer and autumn, and a consequent heavy reliance on hay in winter in an attempt to meet the feed requirements of sheep within the pasture growth pattern. 


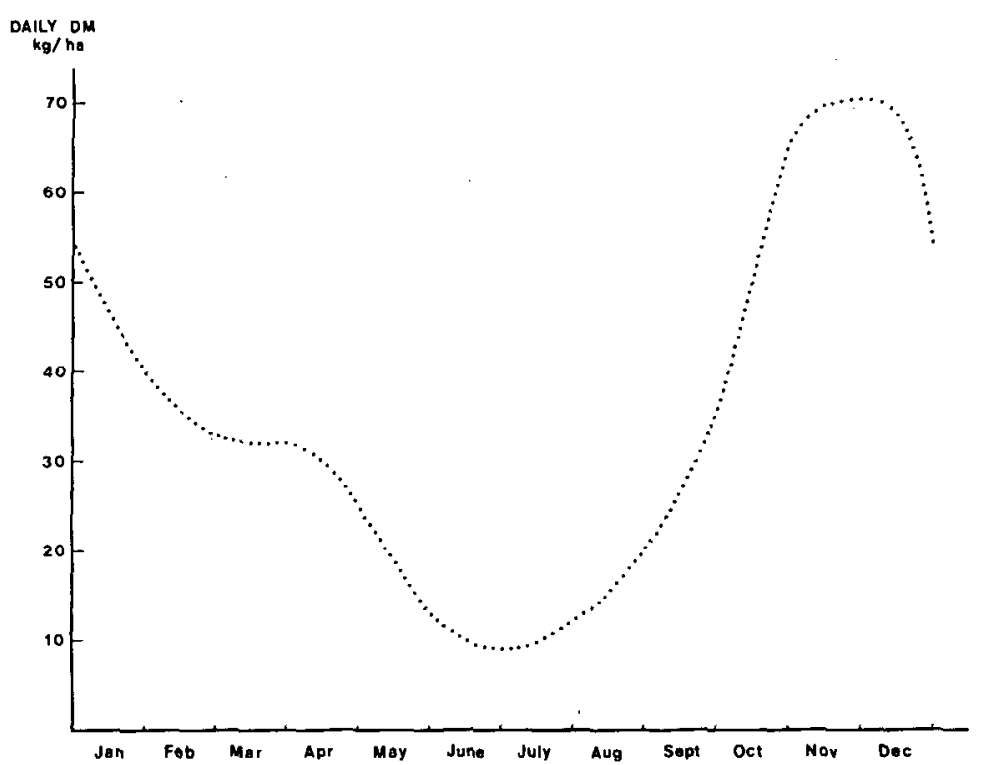

FIG. 1: Daily growth rates of pasture in Southland.

While accepting the view of McMeekan (1956) that increase in stocking rate is the most "powerful weapon" in increasing animal productivity from grassland, one must consider other important factors such as grazing method (McMeekan, loc. cit.; Brougham, 1958), length of rotation (Brougham, 1960; Harris et al., 1973), and grass variety (Harris and Johnston, 1973), which all tend to interact with animal grazing pressure.

Another variable is seasonal alteration in stocking rate. The present study describes the effect of this on the productivity of animals and pastures in a grazing system experiment at Grasslands Division, Gore.

\section{EXPERIMENTAL}

The investigation was conducted over 3 years on experimental units each 1.0 ha in area and subdivided into 10 paddocks, with provision for further division with electric fences. It was sited on Waimumu silt loam, a B-gleyed yellow-grey earth (J. G. Bruce, 
pers. comm.) receiving an average annual rainfall of $825 \mathrm{~mm}$. Fertilizer was applied annually in autumn at $350 \mathrm{~kg} / \mathrm{ha}$ O-6-16. Molybdenum (150 g/ha) was applied every third year. There were duplicates of two treatments named "Standard" and "Variable", salient points of which are shown in Table 1. The Standard treatment is based on an all-grass system with hay wintering and contains many district practices although at a high ewe stocking rate. The Variable treatment has been designed, by difference in seasonal stocking rates, to equate more closely feed requirements with pasture production.

TABLE 1: MAIN TREATMENT FEATURES

\begin{tabular}{lcc}
\hline & Standard & Variable \\
\hline Stocking rate & 23 ewes/ha & 19 ewes/ha \\
Lambing percentage & 125 (natural) & $170^{*}$ \\
Mean lambing date & September 10 & August 31 \\
Weaning & 12 weeks & 12 weeks \\
\hline
\end{tabular}

“Achieved by use of 750 i.u./ewe pregnant mare's serum.

Each unit was self-contained to the extent that all feed for its flock of sheep was grown on the unit but replacement ewes were bought annually in autumn at a rate of about $20 \%$ of the flock. Ewes were Border Leicester $\times$ Romney and were mated to Suffolk rams. Both ewes and lambs were weighed periodically, with emphasis being on key periods (e.g., lambs at birth and weaning; ewes at flushing and tupping).

Lambs were sold for slaughter. in three drafts annually with the first draft occurring at weaning, and yields and gradings of carcass were obtained. Wool was measured on a greasy basis.

Rotational grazing was practised throughout, and herbage dry matter (DM) yields were measured before grazing the paddock. Pasture capacitance-meter readings were taken from up to 20 randomly chosen sites in the 100-m" paddock, and at a site chosen to represent the mean of these readings a $0.28-\mathrm{m}$ ' quadrat was cut with hand shears to a height of $1 \mathrm{~cm}$. Botanical composition measurements were made at each grazing. After grazing, assessment of herbage residue was made, and at the end of each month pasture yield measurements were made over the whole of each unit to assess feed reserves, using the capacitance meter. 


\section{RESULTS AND DISCUSSIONS}

\section{PASTURE AND UtILIZATION}

Pasture composition of the two units stabilized in the first year at a similar composition, as follows:

$\begin{array}{lr}\text { Perennial ryegrass } & 60 \% \\ \text { White clover } & 18 \% \\ \text { Other grasses } & 20 \% \\ \text { Weed } & 2 \%\end{array}$

Other grasses included browntop (Agrostis tenuis), goosegrass (Bromus mollis) and Poa spp. White clover content varied from $34 \%$ in summer to a low $4 \%$ in July.

Rotational grazing was practised throughout the year despite the observation (P. J. Hook, pers. comm.) that about $90 \%$ of farmers in the area set stock from lambing to weaning. There were several reasons for our departure. First, there is considerable evidence (Brougham, 1959, 1960) that more herbage is produced under infrequent defoliations than under frequent hard defolia tions which are represented by continuous grazing. The second advantage of rotational grazing is that the amount of herbage available can be assessed, which allows planning and the equating of animal requirements and feed supply. Rotation length was varied either according to pasture availability or to the current or future needs of animals. Monthly values are presented in Table 2.

The rotation length in September and October in the Variable treatment was a compromise between avoiding damage fror 1

TABLE 2: MEAN NUMBER OF DAYS TO COMPLETE ROTATION

\begin{tabular}{lcc} 
& Standard & Variable \\
\hline January & $\mathbf{2 8}$ & $\mathbf{4 0}$ \\
February & $\mathbf{3 4}$ & $\mathbf{4 4}$ \\
March & $\mathbf{3 6}$ & $\mathbf{4 7}$ \\
April & $\mathbf{4 6}$ & $\mathbf{5 0}$ \\
May & $\mathbf{5 0}$ & $\mathbf{8 6}$ \\
June & $\mathbf{4 1}$ & 113 \\
July & $\mathbf{W}$ & 99 \\
August & $\mathbf{5 6}$ & 31 \\
September & $\mathbf{2 5}$ & 19 \\
October & $\mathbf{2 5}$ & $\mathbf{2 2}$ \\
November & $\mathbf{2 5}$ & $\mathbf{2 5}$ \\
December & $\mathbf{2 4}$ & $\mathbf{4 0}$ \\
\hline
\end{tabular}


treading and grazing in periods of slow growth (Harris and Brown, 1970; Harris and Turner, unpublished data) and meeting the feed requirements of the grazing animals. Even with the management adopted, feed supply was sub-optimal in those months. A faster rotation in September in that treatment would have the effect of providing more adequate feed initially, but, with the low growth increment, the effect of rapid frequency of defoliation on short regrowth would eventually be more deleterious to the animals' feed supply, and it is believed that lamb growth rates would be depressed below those obtained.

Contrasts in pasture utilization patterns between the two systems are depicted in Fig. 2.

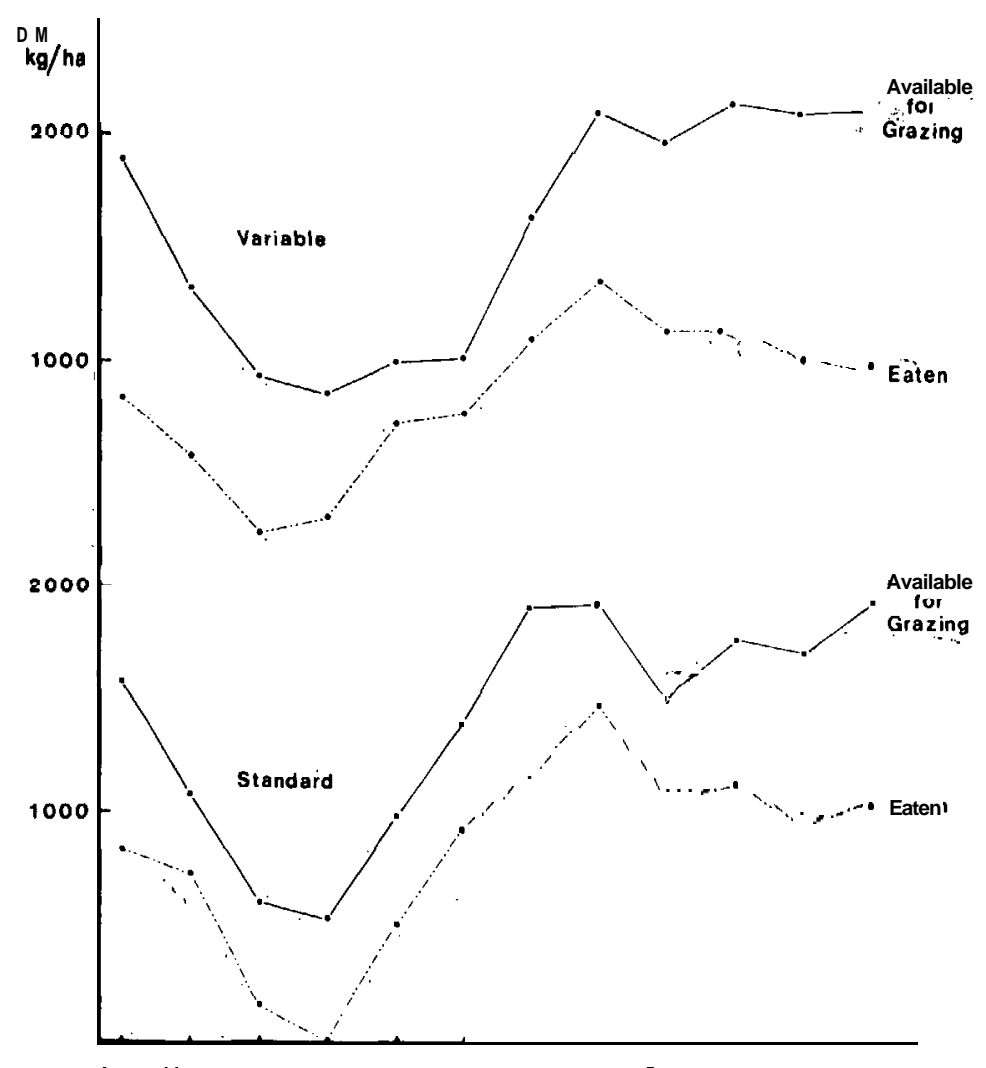

Apr May June July Aug Sept Oct Nov Dec Jan Feb Ma r

Fig. 2: Estimates of pasture available and eaten. 
The amount of pasture available for grazing and the estimate of monthly consumption are somewhat interdependent, but there is sufficient contrast between the systems to make them valuable.

Pasture availability fluctuates less widely in the Variable than in the Standard treatment. This suggests that there is a better relationship in the former treatment between the feed requirement of all animals and its supply. Hay conservation is an important feature, and if the amounts conserved (Table 3) are added to give total herbage availability there is even greater fluctuation in the Standard treatment.

TABLE 3: MEAN AMOUNTS OF HAY CONSERVED AND EATEN (kg DM/ha)

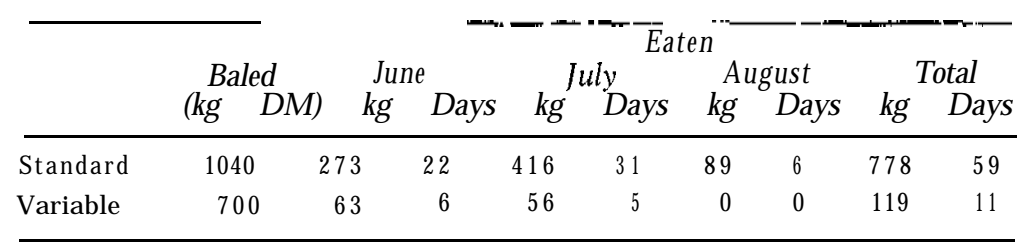

Although the amount of hay made is important to the animal feeding programme in winter, particularly in the Standard unit where $75 \%$ of the hay DM conserved was eaten (cf. $17 \%$ in the Variable), cutting remains an important pasture management tool as it stimulates vegetative production, and pastures used for hay appear more vigorous in autumn. Hard grazing can be used for seedhead control, but the effect of this can often be damaging, particularly on white clover where lengths of stolon are sometimes ripped out (Brougham et $a l ., 1978$ ) and the treading effect occurs under summer conditions (Brown, 1968a).

All-hay feeding has taken place on a straw pad not only to allow measurement but also to avoid the pugging damage inherent in treading wet soils (Edmond, 1958; Brown, 1968b). With the high cost of hay compared with pasture in all-grass wintering (Hook, 1976), this effect is important economically. However, the use of conservation in pasture management described previously should be considered, and in the Variable system use has been made of hay to lessen treading damage even though it may not have been necessary to supplement pasture. It is probable that sole use of pasture in the Variable unit would have been possible in winter, but the results in spring would have exaggerated the feed deficiency already described. 
Although the paired lines in Fig. 2 parallel one another to a degree, in the Variable treatment there are two divergences of major importance. After. summer when stocking rates are reduced by lamb sales, a continuation of this divergence creates feed reserves of growing pasture so important to the concept of all-grass wintering (Brown and Harris, 1972).

In spring, Variable pasture reserves were very low. In fact they are less adequate than depicted, for some of this herbage is not ready for grazing and to so use it would be extremely damaging to regrowth (Harris and Brown, 1970). Pasture intake, determined by measurements before and after grazing, is shown in Table 4 , where monthly values per ewe or ewe-and-lamb combination are described. These figures appear sub-optimal when compared with those of Jagusch and Coop (197 1) or Rattray (1977).

TABLE 4: MEAN DAILY INTAKE (kg DM/ewe)

\begin{tabular}{|c|c|c|c|c|}
\hline & \multicolumn{2}{|c|}{ Standard } & \multicolumn{2}{|c|}{ Variable } \\
\hline & Pasture & Hay & Pasture & Hay \\
\hline January & 1.6 & & 1.9 & \\
\hline February & 1.5 & & 1.9 & \\
\hline March & 1.5 & & 1.7 & \\
\hline April & 1.2 & & 1.5 & \\
\hline May & 1.0 & & 1.0 & \\
\hline June & 0.8 & 0.5 & 0.5 & 0.6 \\
\hline $\begin{array}{l}\text { July } \\
\text { August }\end{array}$ & 0.9 & $\begin{array}{l}0.6 \\
0.6\end{array}$ & $\begin{array}{l}0.7 \\
1.2\end{array}$ & $\frac{0.6}{-}$ \\
\hline September & 1.3 & & 1.3 & \\
\hline October & 1.6 & & 1.9 & \\
\hline November & 2.1 & & 2.1 & \\
\hline December & 1.5 & & 1.9 & \\
\hline
\end{tabular}

Another effect of grazing short herbage under wet conditions is teeth wear consequent on ingesting large quantities of soil (Healy, 1967). Eye assessment of ewes' teeth in autumn of each year suggested that attrition was higher in the Variable unit than in the Standard, although doubt has been expressed by some farmers as to whether teeth wear is an important factor when there is no reliance on a brassica crop.

\section{Animal Performance}

Ewe liveweights at three. key times and estimates of wool production are presented in Table 5. 
TABLE 5: EWE LIVEWEIGHTS AND WOOL PRODUCTION

\begin{tabular}{ccccccc}
\hline & \multicolumn{2}{c}{ Liveweights } & \multicolumn{2}{c}{ (kg/ewe) } & \multicolumn{2}{c}{ Weight $(\mathrm{kg})$} \\
& Flushing & Pre-lambing & Weaning & Per Ewe & Per Ha \\
\hline Standard & 58.6 & 61.7 & 61.9 & 5.6 & 128 \\
Variable & 58.0 & 64.6 & 60.7 & 5.2 & 100 \\
P & n.s. & & n.s. & n.s. & $* *$ \\
\hline
\end{tabular}

The important aspect, as far as viability of both systems is concerned, is that these liveweights appear satisfactory throughout. The difference in pre-lambing liveweight is presumably attributable to the higher number of lambs being carried by the Variable ewes.

Losses in ewe liveweight of 7 to $9 \mathrm{~kg}$ are planned during the early pregnancy period, and to achieve this, $0.6 \mathrm{~kg} \mathrm{DM} /$ ewe/day is fed, either as hay in the Standard or as a calculated ration of grass in the Variable treatment. An increase in quantity and/or quality is provided in the pre-lambing period. These restrictions are necessary to allow an all-grass wintering technique to be adopted, and provided the plane of nutrition is lifted to preserve the health of the ewe (Wallace, 1959) there is apparently no deleterious effect on the animals.

Wool weights are a reflection of stocking rate with no difference in weight per ewe.

Significant lamb data are presented in Table 6.

TABLE 6: SIGNIFICANT LAMB LIVEWEIGHT PERFORMANCE AND CARCASS WEIGHT

\begin{tabular}{ccccc}
\hline & $\begin{array}{c}\text { Birth Wt. } \\
\mathrm{kg} / \mathrm{lamb}\end{array}$ & $\begin{array}{c}\text { Weaning Wt. } \\
\mathrm{kg} / \mathrm{lamb}\end{array}$ & $\begin{array}{c}\text { Daily l.w.g. } \\
\text { Birth-Weaning } \\
(\mathrm{g})\end{array}$ & $\begin{array}{c}\text { Carcass } \\
\mathrm{kg} / \mathrm{ha}\end{array}$ \\
\hline $\begin{array}{c}\text { Standard } \\
\text { Variable }\end{array}$ & 5.0 & 25.1 & 241 & 441 \\
$\mathrm{P}$ & 4.4 & 22.4 & 212 & 474 \\
$* *$ & $* *$ & & \\
\hline
\end{tabular}

$* \mathrm{P}<0.05 ; *: * \mathrm{P}<0.01$.

The main features of these data are that lambs in the Standard treatment have a higher birth weight, a higher growth rate from birth to weaning, and consequently a higher weaning weight (attributable to a higher proportion of single lambs). Despite this, higher weight of carcass was produced from the Variable unit at a mean weight of $14.7 \mathrm{~kg} /$ carcass. 


\section{CONCLUSION}

This experiment provides adequate illustration of some principles of pasture and animal management which are fundamental to the successful implementation of the technique described as "all-grass wintering", or perhaps better as "all-grass farming", as wintering is dependent on management at other times of the year. Important factors are:

1. Stocking rate must be sufficient to make effective use of the pasture growth but not so high that there is heavy reliance on winter supplement. This has been illustrated by the results presented in this paper. There are suggestions that individual performance of animals should be emphasized as the most effective way of achieving high productivity. Higher fecundity is an important factor in this, but efficient systems of feeding animals must be adopted. Such systems appear stocking rate-dependent.

2. Pastures must be vigorous, with management systems designed to provide growing pasture surpluses for later use. Lambing date is important in relation to feed supply, and although it is accepted that later lambing often coincides with a better spring growth rate than early lambing, effects in autumn require attention. Pasture growth rates decline as autumn advances, and the high animal requirement at flushing and tupping (Jagusch and Coop, 1971) may not allow pasture supply for wintering to be adequate. Consequent over-utilization in winter and early spring may in fact give a disadvantage to later lambing, but of course these effects are profoundly affected by weather conditions from summer-autumn onwards.

3. An assessment of the amounts of feed available and an equation of these with animal requirements, with forward projection and accounting for estimated pasture growth, are essential. The feeding programme must take into account the different animal requirements depending on physiological state. Projection may alter the short-term feeding plans for overall gain.

4. Treading on wet soils not only wastes feed but also restricts the regrowth potential. Recent work (Harris and Turner, unpub.) shows that several grazings in winter depress spring regrowth; hence feed planning should where possible avoid a second cycle in winter. There is little point in achieving a cheap wintering system if the result is an inadequate feed supply for lactating animals in spring. 